\title{
Microstructural Properties of Semisolid Welded Joints for AISI D2 Tool Steel
}

\author{
(Sifat Mikrostruktur Penyambungan Terkimpal Separa Pepejal Untuk Keluli Perkakas AISI D2)
}

M.N. Mohammed*, M.Z. Omar, J. Syarif, Z. Sajuri, M.S. Salleh \& K.S. Alhawari

ABSTRACT

The aim of this study is to investigate experimentally the microstructural evolution of the joints using ledeburitic AISI D2 Tool Steel parts. The application of a new process of the semisolid joining of two parts of AISI D2 cold-work tool steel is proposed using a partial remelting method. Samples were heated in an argon atmosphere up to $1300^{\circ} \mathrm{C}$ and held for 10 minutes. Metallographic analyses along the joint interface showed a smooth transition from one to the other and neither oxides nor microcracking was observed. The current work successfully confirmed that avoidance of a dendritic microstructure in the semisolid joined zone and high bonding quality components can be achieved without the need for force or complex equipment when compared to conventional welding processes.

Keywords: Thixo-joining; direct partial re-melting; cold-work tool steel

ABSTRAK

Kajian ini dijalankan bertujuan untuk menyelidik secara eksperimen tentang evolusi mikrostruktur yang berlaku pada sambungan keluli perkakas ledubritik AISI D2. Penggunaan proses baharu untuk menyambungkan dua bahagian keluli perkakas kerja-sejuk AISI D2 dicadangkan dengan menngunakan kaedah pemanasan separa. Sampel dipanaskan di dalam atmosfera argon sehingga $1300^{\circ} \mathrm{C}$ selama 10 minit. Analisis metalografi sepanjang permukaan sambungan menujukkan peralihan yang rata daripada satu sama lain dan tiada berlaku pengoksidaan ataupun keretakan mikro yang kelihatan. Kajian ini berjaya mengesahkan pengelakan mikrostruktur dendritik di kawasan zon sambungan separa pepejal dan komponen mempunyai kualiti ikatan yang tinggi boleh dicapai tanpa memerlukan daya dan perkakasan yang kompleks jika dibandingkan dengan proses kimpalan konvensional.

Kata kunci: Sambungan-tikso; pemanasan separa pepajal; keluli perkakas kerja-sejuk

\section{INTRODUCTION}

AISI D2 cold work tool steels is high carbon and high chromium-contained steel which is used extensively in a variety of machining and manufacturing processes such as blanking dies, mill rolls, punches etc according to its attractive properties such as high wear resistance, high compressive strength, high hardness after hardening and good dimension stability during heat treatment (Mohammed et al. 2013a). Due to the growing demand for cold-work tool steel in various industrial applications, it is crucial to improve the welding technique for joining cold-work tool steel. However, welding this type of material is very difficult and it is almost impossible to achieve a good result using conventional processes. In order to minimize the joining problems of steels, joining in the thixotropic state (thixojoining) is considered to be an effective alternative joining method. The thixojoining process is developed on the basis of semi-solid metal (SSM) processing, which takes place when the material is between solidus and liquidus temperatures, i.e. when the material shows thixotropic behaviour (Mohammed et al. 2012 \& Alhawari et al. 2013).

Metal in a thixotropic state has many features such as high softness, good flowability, superb workability and excellent join ability (Kiuchi et al. 2002 \& Mohammed et al. 2013b). The thixojoining technique has various advantages when compared with conventional joining methods. For instance, it can be used to produce functional components made from multimaterials and can minimize the defects inherent in the conventional welding process. In addition, thixojoining can be used to join low-melting-point metal with high-melting-point metal (Kiuchi et al. 2000). Recent research activities showed that, there are three methods that can be used in the thixojoining process, namely, combining forming and bonding in one step (Baadjou et al. 2006), using a thixotropic metal as filler for joining materials (Mendez et al. 2002), and joining two metals that have a thixotropic property (Mohammed et al. 2013c). The aims of the present study were to investigate the prospect of joining D2 tool steel in the semisolid state and characterize interfacial microstructure and metallurgical joints which are accomplished in this novel process.

\section{EXPERIMENTAL PROCEDURE}

AISI D2 cold-work tool steel in annealed condition was used. The chemical composition of the starting material 
determined by X-ray fluorescence (XRF) technique is shown in Table 1. The first step involved the process of cutting the base metal into samples with a size of $\Phi 16 \times 100 \mathrm{~mm}$ and cutting an insert metal into samples with a diameter of $\Phi 7 \times$ $18 \mathrm{~mm}$ as shown in Figure 1. In the second step, each sample was immersed into a pickling solution with a concentration of $40 \mathrm{ml} \mathrm{HCL}(37 \%)+60 \mathrm{ml} \mathrm{H} \mathrm{O}$ for 5 minutes to get rid of rust and descale the metal to obtain a clean surface.
In the third and final preparation step, the sample was washed in acetone followed by rinsing with distilled water and then dried in air. Samples from the direct partial remelting experiments were carefully ground and polished to obtain mirror surfaces. Microstructural characterization was carried out by using a BX-51 Olympus optical microscope. All samples were etched using Villela reagent to reveal their microstructures.

TABLE 1. Chemical composition (wt.\%) of AISI D2 cold-work tool steel by XRF technology

\begin{tabular}{ccccccccccccc}
\hline $\mathrm{C}$ & $\mathrm{Si}$ & $\mathrm{Mn}$ & $\mathrm{P}$ & $\mathrm{S}$ & $\mathrm{Cr}$ & $\mathrm{Ni}$ & $\mathrm{Mo}$ & $\mathrm{V}$ & $\mathrm{W}$ & $\mathrm{Cu}$ & $\mathrm{Fe}$ \\
\hline 1.55 & 0.258 & 0.239 & 0.025 & 0.01 & 11.2 & 0.197 & 0.79 & 0.85 & 0.2 & 0.08 & Balance \\
\hline
\end{tabular}

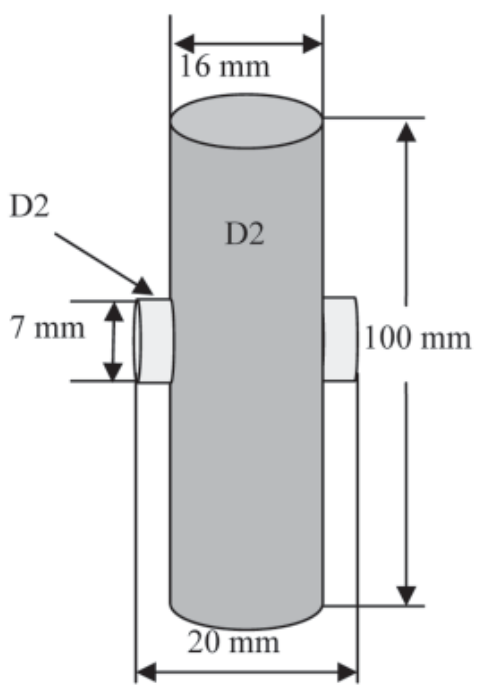

FIGURE 1. Diagram of the combination of the AISI D2

JMatPro (Java-based Material Properties) is a software that was developed to augment thermodynamic calculations by incorporating diverse theoretical material models and a properties database that allows quantitative calculation of the requisite material properties to be made within a larger software structure (Salleh et al. 2014). Here, JMatPro software is used to estimate the solidus and liquidus temperatures as well as the liquid fraction profile (LFP) within the semisolid zone.

Direct partial remelting (DPRM) is considered one of the most effective solid state routes to produce a nondendritic microstructure especially for high melting point metals when the metal is directly heated to a temperature between solidus and liquidus (Omar et al. 2011). A direct partial remelting experiment was performed using a vertical, high temperature carbolite furnace with protective atmosphere of argon gas. When the furnace had reached the predefined temperature, the sample (base and insert) was lowered into the hottest place $\left(1300^{\circ} \mathrm{C}\right)$ of the furnace by using chromel wire and held there for 10 minutes after which it was subjected to air cooling to room temperature.

\section{RESULTS AND DISCUSSION}

STARTING MATERIAL

The as-received material contains surplus arrays of coarse large carbides with smaller carbides distributed homogeneously in a ferrite matrix parallel to the working direction, as shown in Figure 2. This structure has been identified in annealed cold-work tool steel (Omar 2009) and thus confirms that soft annealing treatment had been carried out on the as-received material as described by the supplier.

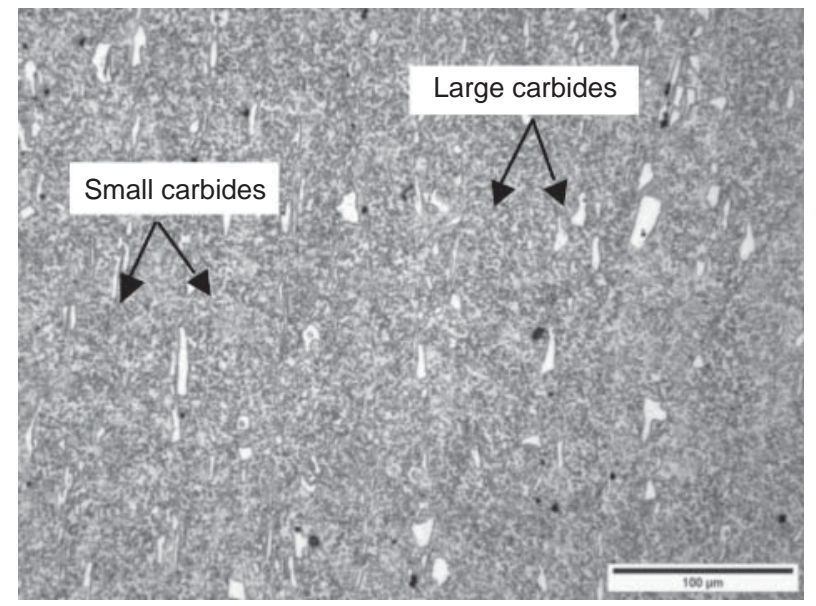

FIGURE 2. Optical micrographs of as-received AISI D2 tool steel

Figure 3 shows the LFP curves which indicate that the volume percentage of liquid, as calculated by JMatPro, at $1300^{\circ} \mathrm{C}$ for AISI D2 is around $27 \%$. Furthermore, the phase stability diagrams for as-received AISI D2 show that, at room temperature, the carbides consisted of $\mathrm{M}_{7} \mathrm{C}_{3}, \mathrm{MC}$ and $\mathrm{M}_{23} \mathrm{C}_{6}$ type carbides, and these have been experimentally verified by Mohammed et al. (Mohammed et al. 2013a). 


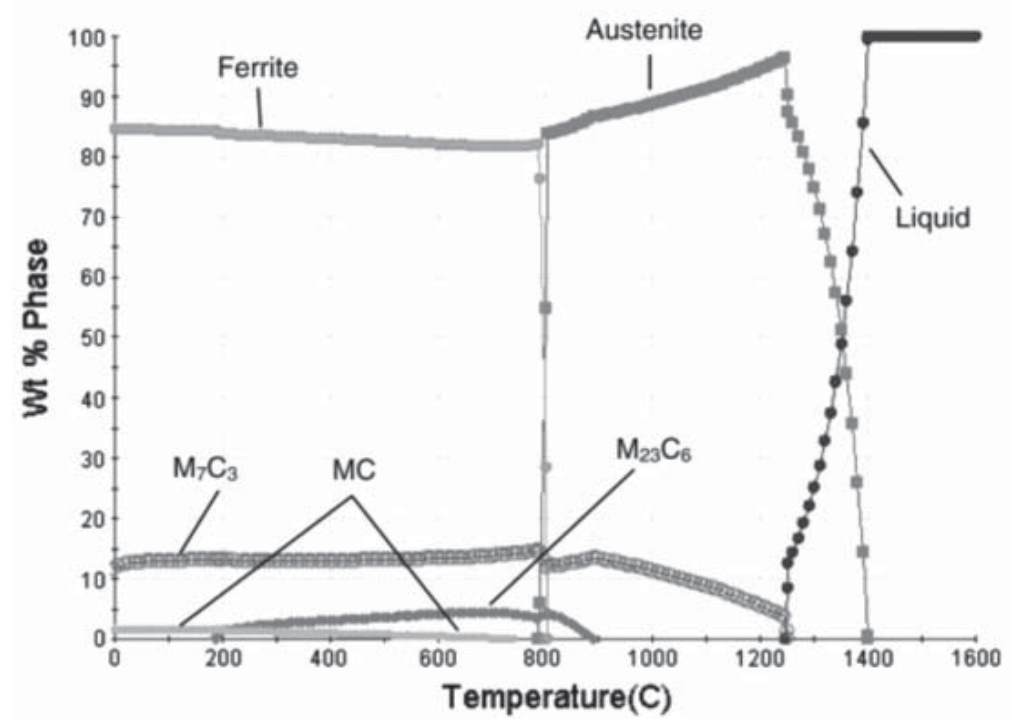

FIGURE 3. Phase equilibrium diagram of AISI D2 tool steel obtained from JMatPro simulation

\section{MICROSTRUCTURE AND INTERFACE CHARACTERISTICS}

The microstructure of the welded joints revealed by the optical microscope is shown in Figure 4. The microstructure has two distinct zones, the base metal and the insert metal zones can be determined by the grains direction. It can also be seen that there is a fine boundary between the base blank and insert with a smooth transition from one metal to the other. At the transition there is no evidence of microcracking or porosity, and the shape of the joint appears to be very smooth and not corrugated. A full penetration welded joint can also be clearly seen, as denoted by grain boundary migration. As for the interfacial reactions that occur during the heating process provided elemental diffusion across the interface and the eutectic liquid starts to spread between the joined surfaces to achieve what appears to be a good joining at the interfaces of both parts. The quality of the transition region between the two parts appears to be high, although additional work will be necessary to optimize the quality of the join.

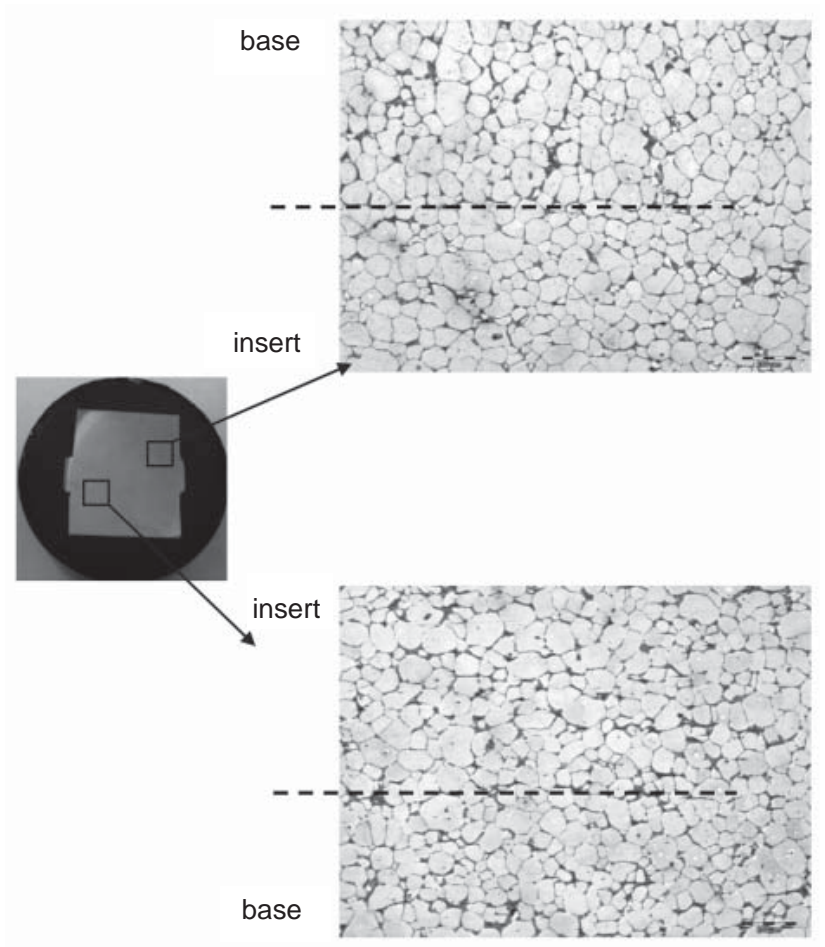

FIGURE 4. Optical micrographs of AISI D2 sample after DPRM experiment 


\section{CONCLUSION}

Novel semi-solid joining of AISI D2 tool steel using direct partial remelting was investigated through this research, which showed enormous potential to be used as an alternative joining technique for tool steel. Microstructural evaluation of the thixo-joining joints shown two distinct zones, the base metal and the insert metal zones that can be distinguished by the grain directions. Based on the results of the experiments conducted in this study, the use of this technique can produce homogeneous properties with high surface quality and avoids the creation of a dendritic microstructure at the join zone. A sound joint without any oxide layer on the interface was achieved. Furthermore, a smooth transition from one part to the other is without evidence of microcracking or porosity. In addition, by using this type of joining process there is no need for force or complex equipment when compared to conventional welding processes. Form the present study; it can be conclude that thixo-joining process can be used safely for cold work tool steel couples.

\section{ACKNOWLEDGEMENTS}

The authors would like to thank Universiti Kebangsaan Malaysia (UKM) and the Ministry of Higher Education (MOHE), Malaysia for the financial support under research grants: GUP-2012-040 and AP-2012-014.

\section{REFERENCES}

Alhawari, K. S., Omar, M. Z., Ghazali, M. J., Salleh, M. S. \& Mohammed. M. N. 2013. Wear properties of A356/ $\mathrm{Al}_{2} \mathrm{O}_{3}$ metal matrix composites produced by semisolid processing. Procedia Engineering 68: 186-192.

Baadjou, R. Shimahara, H. \& Hirt, G. 2006. Automated semi-solid forging of steel components by means of thixojoining. Solid State Phenomena 116-117: 383 386.

Kiuchi, M., Yanagimoto, J. \& Sugiyama, S. 2000. Application of mushy/semisolid joining, Proc. 6th Int. Conf. SemiSolid Processing of Alloys and Composites, Turin, Italy: 235-240.

Kiuchi, M. Yanagimoto, J. \& Sugiyama, S. 2002. Application of mushy/semi-solid joining part-2, Proc. 7th Int. Conf. Semi-Solid Processing of Alloys and Composites, Tsukuba, Japan: 707-712.
Mendez, P. F. Rice, C. S. \& Brown, S. B. 2002. Joining Using Semisolid Metals. Welding Journal Sep.: 181s-187s.

Mohammed, M. N. Omar, M. Z. Salleh, M. S. Zailani, M. A. \& Alhawari, K. S. 2012. Joining Two Metals Via Partial Remelting Method. Journal of Asian Scientific Research 2: 724-730.

Mohammed, M. N. Omar, M. Z. Syarif, J. Sajuri, Z. Salleh, M. S. \& Alhawari, K. S. 2013a. Microstructural Evolution during DPRM Process of Semisolid Ledeburitic D2 Tool Steel, The Scientific World Journal. DOI:10.1155/2013/828926.

Mohammed, M. N. Omar, M. Z. Salleh, M. S. Alhawari, K. S. \& Kapranos, P. 2013b. Semi-solid metal processing techniques for nondendritic feedstock production. The Scientific World Journal. doi:10.1155/2013/752175.

Mohammed, M. N. Omar, M. Z. Salleh, M. S. \& Alhawari, K. S. 2013c. Study on thixojoining process using partial remelting method, Advances in Materials Science and Engineering. doi:10.1155/2013/251472.

Omar, M. Z. Alfan, A. Syarif, J. \& Atkinson, H. V. 2011a. Microstructural investigations of XW-42 and M2 tool steels in semi-solid zones via direct partial remelting route. Journal of Materials Science 46: 7696-7705.

Omar, M. Z. Atkinson, H. V. Howe, A. A. Palmiere, E. J. Kapranos, P. \& Ghazali, M. J. 2009. Solid-liquid structural break-up in M2 tool steel for semi-solid metal processing, Material Science 44: 869-874.

Salleh, M. S. Omar, M. Z. Syarif, J. \& Mohammed M. N. 2014. Thermodynamic Modelling of Al-Si-Cu Alloys for Semisolid Metal Processsing. Journal of Sains Malaysiana 43(5): 791-798.

M. N. Mohammed*, M. Z. Omar, J. Syarif, Z. Sajuri,

M. S. Salleh \& K. S. Alhawari

Department of Mechanical and Materials Engineering

Faculty of Engineering and Built Environment

Universiti Kebangsaan Malaysia

43600 UKM Bangi, Selangor D.E.

Malaysia

Corresponding author; email: mohammed.ukm@gmail. com

Received date: $21^{\text {st }}$ April 2014

Accepted date: $7^{\text {th }}$ October 2014 